\title{
RYTE I WYDRAPYWANE MOTYWY NA NACZYNIACH Z OSTROWA TUMSKIEGO W POZNANIU
}

\author{
INCISED AND SCRATCHED MOTIFS \\ ON UTENSILS FROM OSTRÓW TUMSKI IN POZNAŃ
}

\begin{abstract}
During excavations carried out in Ostrów Tumski by the Institute of Prehistory of the Poznan University, a small collection of utensils was found with incised or scratched motifs which are reminiscent of decorations (Figure1). The collection includes an early medieval mug ( $9^{\text {th }}-$ mid- $10^{\text {th }}$ c.; Figure $2: 1)$ as well as jars and a plate (?; $16^{\text {th }} \mathrm{c}$.; Figure $\left.2: 2-4\right)$ with mysterious signs placed on the receptacles before they were fired (incisions: receptacle 1 and 4 ) and in the course of use thereof (scratched with a sharp object: receptacle 2 and 3). They were excavated in the ducal garden next to the palace and sacral complex (receptacle 1) and the Gothic St. Mary's church and the adjacent cemetery (receptacle 2) as well as in the northern part of the island (receptacles 3 and 4). They were excavated from cultural layers (receptacle 1), from a well's thill (receptacle 2), a wooden waste pond where fish were kept (?; receptacle 4) and a backfill of another well (receptacle 3).

On the early medieval mug, where the neck becomes a body, it the middle of its circumference, parallel to the receptacle's edge, there are signs in the form of a vertical line, a square, another vertical line topped with tiny parallel incisions and two crossing lines incised with a sharp object in a dried utensil before it was fired (Figure 3:1). On the upper part of the body of an almost completely preserved jar, four crossing lines were scratched to form a star, a loop, three intersecting lines - a star, the letter " $Y$ " with three perpendicular lines in the lower part and, slightly lower, a boat /a crescent (?; Figure 3:2). On another jar, in the upper part of its body, next to the handle, a sharp object was used to scratch an inscription made of 6-7 "letters" (Figure 3: 3). At the bottom of a bowl (?), a potter incised with a sharp object a lily and an anchor cross.

While only four specimens have been excavated in Ostrów Tumski in Poznań, and the signs are hard to interpret, an attempt can be made to explain the reasons why they were placed on the receptacles. The incisions on two of them were made before the receptacles were fired, hence they can be attributed to the potters' work. In the case of the mug (Figure 2:1;3:1), the fact that it was made by the same person was emphasized. The act of incising the bottom of the other utensil (Figure 2:4; 3:4) may have something

* ORCID: 0000-0002-5732-4474; Wydział Archeologii UAM, ul. Uniwersytetu Poznańskiego 7, 61-614 Poznań, olgaag@amu.edu.pl.

** ORCID: 0000-0002-2082-8177; Wydział Archeologii UAM, ul. Uniwersytetu Poznańskiego 7, 61-614 Poznań, kockrenz@amu.edu.pl.

*** ORCID: 0000-0003-2603-6100; Wydział Archeologii UAM, ul. Uniwersytetu Poznańskiego 7, 61-614 Poznań, ands@amu.edu.pl.
\end{abstract}


to do with it being made for a specific group of users. On the other hand, the two remaining receptacles were scratched when they were ready so they were marked by the owners at the expense of the utensils' looks. The jug was preserved almost intact (Figures $2: 2 ; 3: 2 ; 4$ ) and could hold 2 litres of liquid. It is covered with symbols meaningful to its owner, perhaps identifying him/her. A piece of the jug (Figures $2: 3,3: 3$ ) bears an inscription which, with some caution, may be interpreted as dialectal words of German or Dutch origin, meaning "my (drinking) utensil". Irrespective of the correctness of "deciphering" the scratched signs, these are undoubtedly unique hand-written inscriptions from the second half of the $16^{\text {th }}$ century. If anything, it is a good reason to devote attention to them.

Keywords: Poznań, 10th-16th centuries, utensils with incised/scratched marks.

Podczas badań wykopaliskowych prowadzonych przez Instytut Prahistorii UAM na Ostrowie Tumskim w Poznaniu pozyskano nieliczny zbiór pojemników oznaczonych poprzez wyrycie lub wydrapanie motywów, które nie noszą cech dekoracji. Na podstawie cech techno-stylistycznych można te naczynia przypisać do dwóch okresów: jedno do IX - połowy X w. (ryc. 2:1), trzy zaś do XVI w. (ryc. 2:2-4; por. Miazga, Sankiewicz i Sikorski 2012, tam dalsza lit.; Lech 2013, s. 67).

Ryty, piktogramy i trudne w interpretacji wyobrażenia sporadycznie rejestrowane były na pradziejowych (por. Gediga 1979; Kwapiński 1987; Makiewicz 1997; Bugaj 1999; Kaczmarek 2002, s. 74-79), średniowiecznych (Skrok 2001, s. 101-105) i nowożytnych (Andrzejewski 1996; Pochylski, Kowalczyk 2012) wyrobach glinianych. Odnotowujemy je głównie na ceramice naczyniowej (Boom 2000, s. 186 i n.; Gedl 2000, s. 124 i n.; Węgrzynowicz 2000, s. 228 i n.), przęślikach, kaflach płytowych z XVI-XVIII w. (Grygiel 1996, s. 183, 184; Supryn 2008, s. 93-99; Fonferek 2011, s. 129 i n.), ceramice budowlanej (Drążkowski, Rozenerska i Kostynowicz 1964, s. 418, ryc. 6-9; Małachowicz 2005, s. 113-115, ryc. 8; Skowrońska 2011, s. 137, ryc. 2) lub bryłkach polepy (Skrok 2001, s. 53-58). Elementy te ryto patykiem lub nożem, wykonywano za pomocą radełka, odciskano w matrycach, malowano pędzelkiem (np. na dzbanie z Janiszewa; Andrzejewski 1996, ryc. 1-4) lub wydrapywano na gotowych wyrobach. Wśród nich wyróżnić można „rysunki” (Kostrzewski 1948; Sikorski 1991, tam dalsza lit.), napisy, daty i inicjały na polepie (Buko 2011, s. 178-180), naczyniach (Malinowska 1961, ryc. 66; Szwed 2004, ryc. 10:3, 6; Marcinkowski 2011, s. 64 i n.), na kaflach (Dąbrowska 1987, s. 132; Janiak 2003, s. 29 i n.; Supryn 2008, s. 93-99), znaki garncarskie (por. Buko 2011, s. 367-376; Janiak 2003, s. 21-24), sygnatury warsztatów (por. Kamiński 1997, s. 230-241) lub inne, nieokreślone znaczeniowo motywy.

Wczesnośredniowieczny kubek oraz wczesnonowożytne dzbany i talerz (?) z poznańskiej wyspy katedralnej zaliczyć można do wyrobów z zagadkowymi znakami, wykonanymi na uformowanych pojemnikach przed ich wypałem (rycie: naczynie 1 i 4) i w trakcie używania (wydrapane ostrym narzędziem: naczynie 2 i 3). Pozyskano je w obrębie gródka książęcego przy zespole pałacowo-sakralnym (por. Kóčka-Krenz 2012b, s. 19 i n.; naczynie 1) i gotyckim kościele NMP z przyległym cmentarzem (naczynie 2) oraz w północnej części wyspy (północny człon grodu, 
zasypywany od XV - pocz. XVI w.; por. Kóčka-Krenz 2012a, s. 17, 18; Lech, Sikorski i Sprenger 2012, s. 220; naczynie 3 i 4). Fragmenty i prawie całe pojemniki (ryc. 1) wydobyte zostały $\mathrm{z}$ warstw kulturowych (naczynie 1 - Ostrów Tumski, stan. 9 [OT 9]), ze spągu studni (naczynie 2 - OT 9) i podobnie datowanego drewnianego odstojnika do przetrzymywania ryb (?; naczynie 4 - OT 13) i z zasypiska drugiej studni (naczynie 3 - OT 13).

\section{OPIS CERAMIKI}

Kubek (naczynie 1; nr inw. OT 9/197/99; 200/99, 203/99; 208/99; ryc. 2:1)

Poniżej poziomu użytkowego palatium zarejestrowano słabo profilowany pojemnik, częściowo obtaczany - tylko w górnej części - na wolnoobrotowym kole garncarskim, po podsuszeniu czerepu wyrównywany kantem drewnianego gładzika. Wypał utleniający, w niekontrolowanych warunkach (ścianka zewnętrzna bardzo ciemnoszaro-brązowa i ciemnobrązowa - 10YR 4/3, 3/2, 3/3; wewnętrzna bardzo ciemnoszara - 10YR 3/1; por. Munsell 1973). Kubek nie nosi wyraźnych śladów użytkowania (brak starć mechanicznych - twardość powierzchniowa ścianek około $2^{0} \mathrm{~W}$ skali Mosha).W miejscu przejścia szyjki w brzusieć na połowie jego obwodu, równolegle do brzegu naczynia, widnieją znaki w postaci pionowej kreski, kwadratu, kolejnej pionowej kreski zwieńczonej równoległymi drobnymi nacięciami i dwóch krzyżujących się kresek, które wyryto ostrym narzędziem na podeschniętym naczyniu przed jego wypałem.

Wymiary naczynia: wysokość - 11,2 cm, średnica wylewu - 10,8-11 cm, średnica lekko wklęsłego dna, z podsypką piasku i niesymetrycznie usytuowanym negatywem po nieruchomej osi koła garncarskiego $-6,8-7 \mathrm{~cm}$. Kubek o pojemności około 0,5 litra.

Dzban (naczynie 2; nr inw. OT 9/394w/08; ryc. 2:2; ryc. 4)

$\mathrm{Z}$ dna studni nowożytnej położonej na placu przy kościele NMP (ryc. 1:2) wydobyto ceglaste naczynie toczone $\mathrm{z}$ odcinanym dnem, pokryte biało-kremową angobą (o odcieniu bardzo bladobrązowym: 10YR 8/3, 8/4 - 7/3, 7/4), wyświecone $-\mathrm{z}$ wyjątkiem dna - na całej powierzchni zewnętrznej. Dzban, z lekko odchylonym w prawo masywnym uchem, został zapewne zanurzony w wybielającym roztworze glinki, gdyż angoba częściowo wlała się do wnętrza pojemnika. Wypał utleniający, kontrolowany, angoba doskonale spieczona z podłożem. Wyrób odznacza się wysokimi walorami użytkowo-estetycznymi dzięki impregnacji i lśniąco -białej powierzchni. Podobne naczynia, będące swego rodzaju naśladownictwem majoliki włoskiej, pojawiały się sporadycznie w XVI w. (Mogilno), choć większą popularność zyskały w kolejnych stuleciach (Lech 2013, s, 67, tam dalsza lit.). Gdyby przyjąć, że dzban był używany przez praworęcznego konsumenta, to na górnej części brzuśca wydrapano ostrzem (patrząc od lewej, od strony ewentual- 


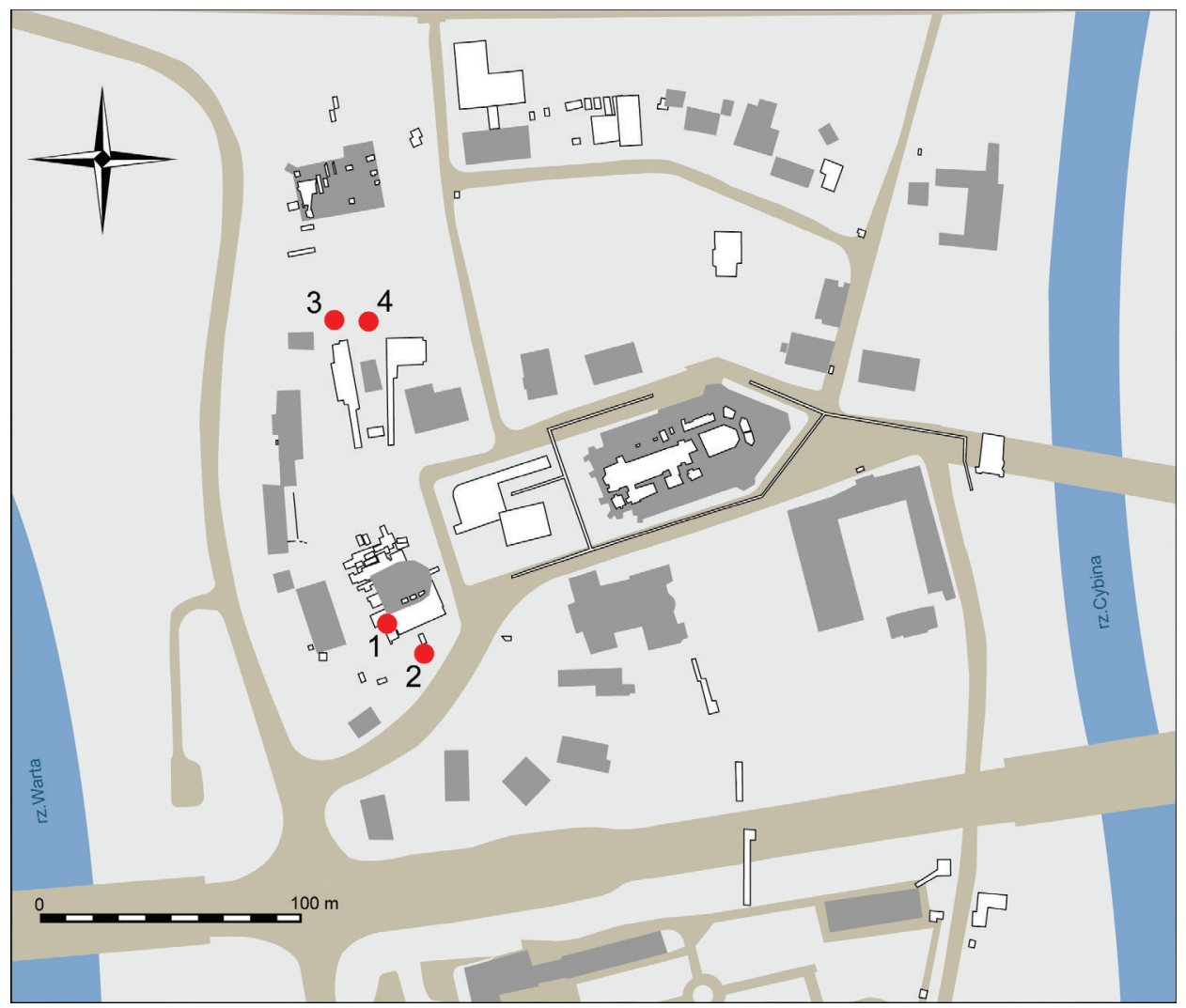

Ryc. 1. Poznań-Ostrów Tumski, stan. 9/10 i 13. Lokalizacja naczyń 1-4 - oprac. O. Antowska-Gorączniak

nego współbiesiadnika): cztery przecinające się kreski tworzące rodzaj gwiazdki, pętelkę, trzy przecinające się kreski - gwiazdka, literę „Y” z trzema prostopadłymi kreskami w jej dolnej części oraz nieco niżej łódkę /sierp księżyca (?; ryc. 3:2). Znaki te zostały wyskrobane na twardej ściance wyrobu ( $>3^{0} \mathrm{w}$ skali Mohsa) jednym pociągnięciem ostrego narzędzia (bez poprawiania czy tuszowania), zapewne jednorazowo.

Wymiary dzbana: wysokość - 22,2 cm, średnica wylewu $-8,6 \mathrm{~cm} \mathrm{z}$ uchem o szerokości $3 \mathrm{~cm}$, średnica brzuśca $-16,6 \mathrm{~cm}$, średnica dna $-11,8 \mathrm{~cm}$. Naczynie o pojemności 2 litrów.

Fragment dzbana (naczynie 3; nr inw. OT13/52w/11; 55w/11; ryc. 2:3)

Pojemnik toczony, ceglasty, pokryty biało-kremową angobą przez zamoczenie i rozprowadzenie glinki szmatką (odcień: 10YR 8/2 - 8/4 i wyświecony na zewnętrznej powierzchni ścianki o grubości $0,35-0,55 \mathrm{~cm}$. Dzban, który został 
1
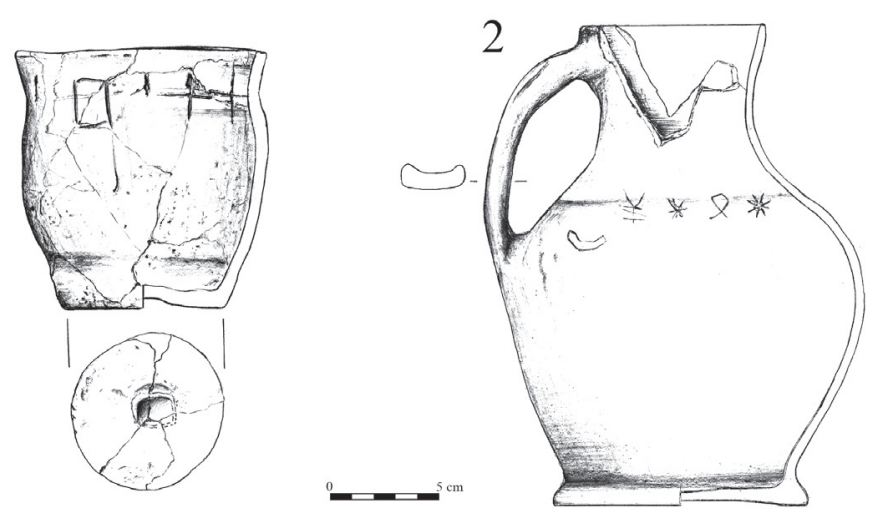

3

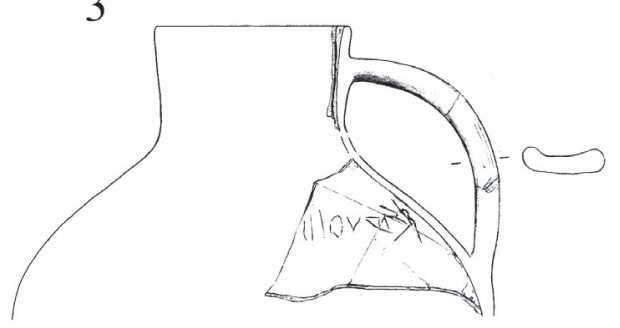

4

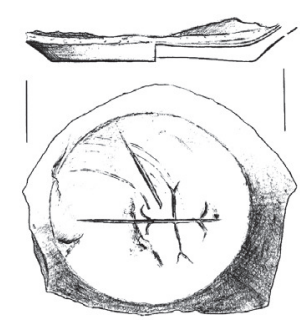

Ryc. 2. Poznań-Ostrów Tumski, stan. 9/10 i 13. Pojemniki z rytami i ,zdrapkami”: wczesnośredniowieczne (1) i wczesnononowożytne (2-4) - rys. O. Antowska-Gorączniak

zbity przy studni na OT 13 (ryc. 1:3), posiada zbliżone walory techno-stylistyczne do naczynia wydobytego ze studni przy kościele NMP (OT 9), choć miał zapewne większą pojemność. Wypał kontrolowany utleniający (przełam jednobarwny, dobrze spieczony). Zapewne już w czasie użytkowania, w górnej części brzuśca - przy uchu, wydrapano ostrym narzędziem rodzaj napisu z 6-7 „liter” (ryc. 3:3). Wydaje się, że naczynie zostało dość szybko wyłączone z użytkowania (brak czytelnych śladów eksploatacji na fragmentach ścianek o twardości $>3^{0} \mathrm{w}$ skali Mohsa).

Wymiary dzbana: maksymalna wydętość brzuśca około $22 \mathrm{~cm}$, średnica wylewu - $9 \mathrm{~cm}$, ucho o szerokości $3,7 \mathrm{~cm}$.

Dno misy (?; naczynie 4, nr inw. OT13/595/11, ryc. 2:4)

Fragment prawie całego odcinanego dna naczynia toczonego, pokrytego na ściance wewnętrznej szkliwem oliwkowym (do dna przywarł osad wapienny?). 
1<smiles>CC(C)(C)CC(C)(C)C</smiles>

2

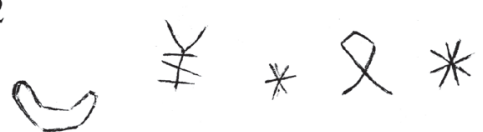

3

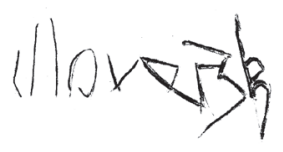

4

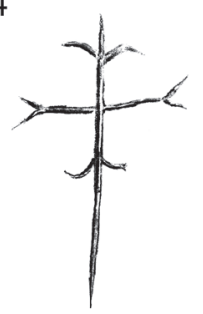

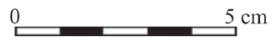

Ryc. 3. Poznań-Ostrów Tumski, stan. 9/10 i 13. Ryty i „zdrapki” - rys. O. Antowska-Gorączniak

Jego zewnętrzna ścianka, powyżej części przydennej, przypuszczalnie pokryta była podobną polewą. Na podsuszonym dnie garncarz ostrym narzędziem wykonał z wolnej ręki (niesymetrycznie) krzyż liliowo-kotwicowy. Wypał utleniający, kontrolowany (odcień czerwonawo-źółty - 5YR 7/6, 7/8 - 6/6, 6/8, przełam jednobarwny, dobrze spieczony).

Wymiary: średnica dna 8,8-9,1 cm, o grubości $0,8 \mathrm{~cm}$.

\section{ANALIZA MATERIAŁÓW}

\section{Motywy ryte}

„Piktogramy” (dla nas „kryptogramy”) zostały wyryte na jednej części kubka datowanego na IX - połowy X w. (ryc. 2:1), podczas gdy druga jego połowa nie została nimi ozdobiona. Trudno rozstrzygnąć, czy były to tylko przypadkowe nacięcia podnoszące chropowatość ścianki dla ułatwienia utrzymania kubka, prymi- 


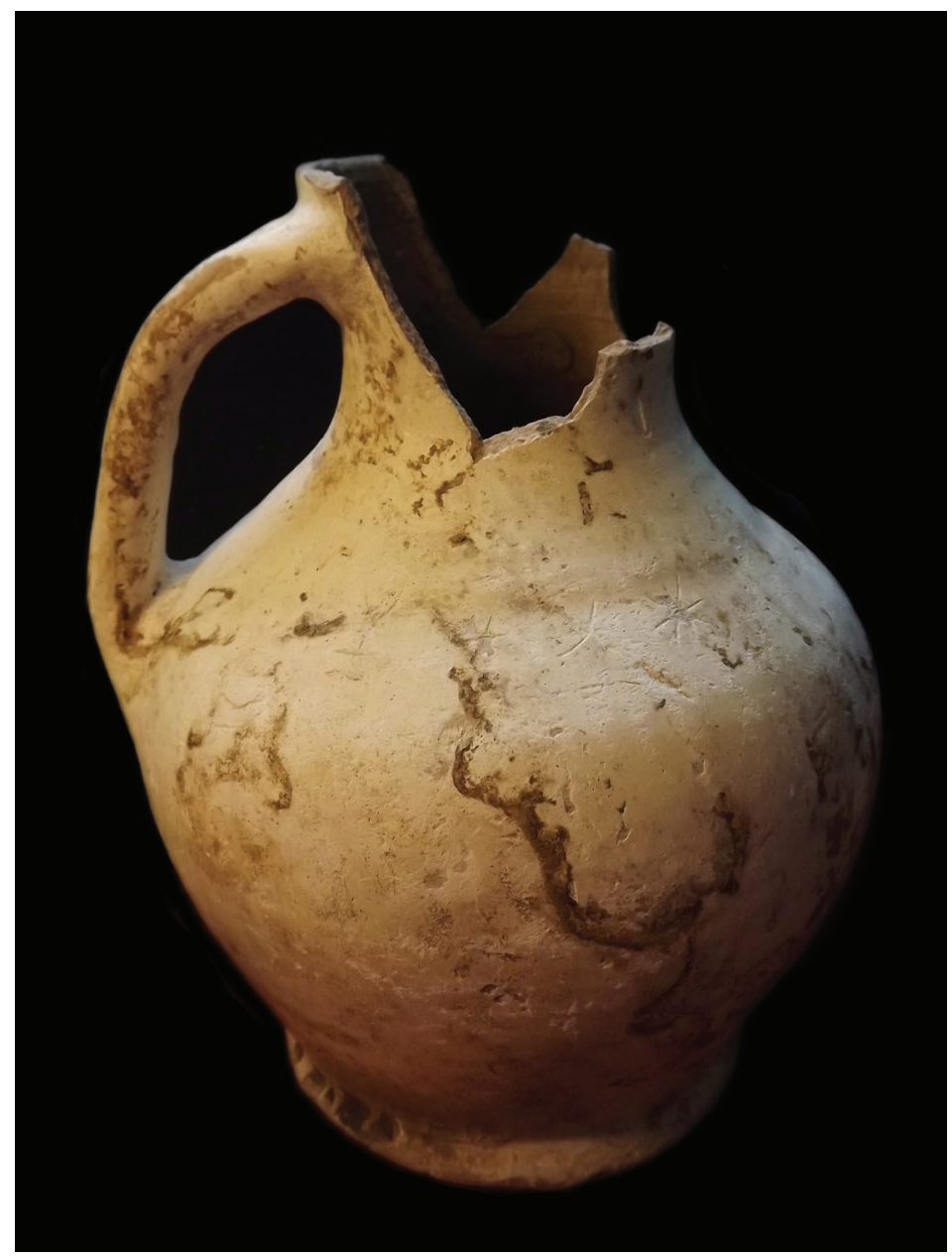

Ryc. 4. Poznań-Ostrów Tumski, stan. 13. Wczesnonowożytny dzban ze studni (ob. 1) - fot. O. Antowska-Gorączniak

tywny ornament, znak wytwórcy, czy też zapis jakiejś informacji. Kreski pionowe i krzyże na wczesnośredniowiecznej ceramice pomorskiej, wielkopolskiej i śląskiej można poniekąd uznać za standardowe, natomiast nieczęsto w górnej części naczynia kreślono prostokąt(-y) (ryc. 3:1). W średniowieczu i w okresie wczesnonowożytnym zgeometryzowane, niekiedy figuralne znaki ryte na ściankach naczyń glinianych pojawiały się raczej sporadycznie (por. Kostrzewski 1948; Sikorski 1991, s. 284-286; Buko 2011, s. 180). Zwykle wykonywane były w warsztatach przez pracowników lepiących garnki na jeszcze plastycznych ściankach wyrobów, przed ich wypałem. 
Z kolei na wczesnonowożytnym dnie misy garncarz wyciął krzyż liliowo-kotwicowy (ryc. 3:4). Element majuskuły „M”, wpisany w pionową belkę łączony jest z imieniem Maryi - Matki współcierpiącej z Chrystusem, natomiast zakończenia poziomej belki podobne są do krzyża kotwicznego, symbolu nadziei (Bąkała 2010, s. 148). Takie oznakowanie dna stanowi przesłankę sugerującą kościelną zastawę stołową, w jakiej być może jadali mieszkańcy wyspy katedralnej w połowie XVI wieku. Pojemniki z rytymi „od ręki” krzyżami na dnach wyrobów toczonych właściwie nie są znane $\mathrm{w}$ inwentarzach późnośredniowiecznych i wczesnonowożytnych. Znak krzyża na naczyniach traktowany był z właściwą atencją, czego przykładem jest m.in. plakietka łekneńska z 2 połowy XVI w. (Sikorski 2003, s. 96, ryc. 13:1).

\section{Motywy wydrapane}

Ryty przy uchach dzbanów, wykonane jednym pociągnięciem ostrza, są naniesione na okazy znalezione w studniach (ryc. 2:2 i 2:3). Starcia mechaniczne w górnej części ucha dzbana (ryc. 2:2) ze studni położonej przy trakcie biegnącym przez Ostrów Tumski od mostu na Warcie do mostu na Cybinie sugerują intensywną eksploatację tego pojemnika (nie do czerpania wody). Na ściankach tego dzbana zachowało się pięć znaków wydrapanych w równych odstępach co $1,1 \mathrm{~cm}$. Może pośpiesznie wydrapano tu jakieś umowne znaki konsumenckie (,z księżycem” na początku oraz cyframi: 1?, 0 (,gwiazdka”)? 4 („pętelka”) i 0 (,gwiazdka”)? por. Encyklopedia 1971, s. 432-435; Janiak 2003, il. 98), miara objętości lub wypite „garnce”. Równie prawdopodobne wydaje się domniemanie, że mogą to być sygnatury właściciela, który mógł „rysować” dowolne znaki na swoim dzbanie, niż dzieło garncarza (obniżenie walorów estetycznych wyrobu). Jego pojemność wynosi dokładnie 2 litry.

$\mathrm{Na}$ drugim, bardzo podobnym $\mathrm{z}$ technicznego punktu wiedzenia dzbanie, nieporadnie wydrapano napis: „Moverzk”, z kreską poziomą nad literą „z”, sugerującą skrót (?; ryc. 3:3; wymiary: długość 5,7 cm, wysokość liter 1,1-3,7 cm - Szántô 1986, s. s. 250). Pomimo nierównej płaszczyzny (krzywizna górnej części brzuśca) piszący wydrapał napis właściwie jednym pociągnięciem ostrza, bez żadnych poprawek i uzupełnień. Znane są przykłady odciskania napisów na ceramice naczyniowej z XV- XVII w. (Pochylski, Kowalczyk 2012, s. 231 i n.) i kaflach (Janiak 2003, il. 98; Krasnokutská 2005, s. 62 , tab. 15, 1, 2), natomiast ich wyskrobywanie jest rzadkością. 


\section{KONKLUZJE}

Mimo iż na poznańskim Ostrowie Tumskim pozyskano zaledwie cztery okazy zawierające trudne do interpretacji znaki, można podjąć próbę wyjaśnienia przyczyn ich umieszczenia na tych pojemnikach. Ryty na dwóch z nich zostały wykonane jeszcze przed wypałem naczyń, stąd można je uznać za poczynania garncarzy. Jest rzeczą niewykluczoną, iż w przypadku kubka (ryc. 2:1; 3:1) mamy do czynienia z zaakcentowaniem jego przynależności do samego wytwórcy. Umieszczenie rytu na dnie drugiego naczynia (ryc. $2: 4 ; 3: 4$ ) może mieć natomiast związek z jego przeznaczeniem dla określonego grona użytkowników. Natomiast dwa pozostałe pojemniki zostały oznakowane w czasie, gdy były już całkiem gotowe, zostały więc naznaczone przez swych posiadaczy kosztem ich estetyki. Zachowany niemal w całości dzban (ryc. 2:2; 3:2;4), który mieścił 2 litry napoju, pokryty został symbolami zrozumiałymi dla właściciela, może też jego identyfikującymi. Natomiast na fragmencie dzbana (ryc. 2:3, 3:3) widnieje napis, który - z pewną dozą ostrożności - można próbować odczytać jako gwarowe wyrazy pochodzenia niemieckiego lub holenderskiego, oznaczające „mój przybór” (w tym przypadku - do picia). Niezależnie od stopnia poprawności „odczytania” tych wydrapanych znaków, na pewno są to unikatowe próby odręcznego zapisu z 2 połowy XVI w. i choćby $z$ tego względu zasługują na uwagę.

\section{LITERATURA}

Andrzejewski A. 1996, Nieznane źródło ikonograficzne do dziejów garncarstwa na Kujawach, „Kwartalnik Historii Kultury Materialnej", R. 44, z. 4, s. 403-408.

Bąkała K. 2010, Historia symboliczna znakiem, herbem i barwa pisana. Podręczny słownik, Warszawa. Boom van den H. 2000, Ceramika jako nośnik znaczenia: rozważania nad zdobnictwem ceramiki, w: Kultura symboliczna kręgu pól popielnicowych epoki brązu i wczesnej epoki żelaza w Europie Środkowej, red. B. Gediga, D. Piotrowska, Warszawa-Wrocław-Biskupin, s. 183-200.

Bugaj E. 1999, Motywy figuralne na ceramice germańskiego kręgu kulturowego, Poznań.

Buko A. 2011, Archeologia Polski wczesnośredniowiecznej. Odkrycia - hipotezy - interpretacje, Warszawa.

Dąbrowska M. 1987, Kafle i piece kaflowe w Polsce do końca XVIII wieku, Wrocław-Warszawa-Kraków -Gdańsk-Łódź.

Drążkowski H., Rozenerska M., Kostynowicz R. 1964, Prace konserwatorskie w katedrze kamieńskiej w latach 1962-1963, „Materiały Zachodniopomorskie”, t. 10, s. 417-425.

Encyklopedia 1971, Encyklopedia wiedzy o książe, red. A. Birkenmajer, B. Kocowski, J. Trzynadłowski, Wrocław-Warszawa-Kraków.

Fonferek J. 2011, Tematy biblijne na kaflach ze zbiorów Muzeum Archeologiczno-Historycznego w Elblagu. Przyczynek do ikonografii przedstawien,, „Elbląskie Studia Muzealne”, t. 2, s. 128-139.

Gediga B. 1979, Sztuka ludności kultury pomorskiej a sztuka ludności kultury tużyckiej, w: Problemy kultury pomorskiej, red. T. Malinowski, Koszalin, s. 71-94.

Gedl M. 2000, Elementy halsztackie w budowie $i$ wyposażaniu grobów ludności kultury tużyckiej na Ślasku, w: Kultura symboliczna kręgu pól popielnicowych epoki brąu i wczesnej epoki żelaza w Europie Środkowej, red. B. Gediga, D. Piotrowska, Warszawa-Wrocław-Biskupin, s. 115-128.

Grygiel R. 1996, Dzieje rezydencji, w: R. Grygiel, T. Jurek, Doliwowie z Nowego Miasta nad Warta, Dębna i Biechowa. Dzieje rezydencji i ich właścicieli, Łódź, s. 11-284. 
Janiak T. 2003, Kafle gotyckie w zbiorach Muzeum Początków Państwa Polskiego w Gnieźnie, Gniezno. Kaczmarek M. 2002, Zachodniowielkopolskie społeczności kultury lużyckiej w epoce brązu, Poznań. Kamiński R. 1997, Renesansowe kafle Hansa Bermana z klasztoru pocysterskiego w Kotbaczu, „Materiały Zachodniopomorskie", t. 43, s. 229-245.

Kostrzewski B. 1948, Naczynie wczesnohistoryczne z Radzimia w pow. obornickim z ornamentem postaci ludzkich, „Slavia Antiqua”, t. 1, s. 568-572.

Kóčka-Krenz H. 2012a, Badania Instytutu Prahistorii UAM na Ostrowie Tumskim w Poznaniu w latach 2008-2011, [w:] Poznań we wczesnym średniowieczu, red. H. Kóčka-Krenz, t. VII, Poznań, s. 7-22.

2012b, Na wyspie Ostrów, przy której dziś jest Poznań..., Poznań.

Krasnokutská T. 2005, Středověké a novověké kachle z Opavy. Katalog nálezů z archeologických výzkumů, „Archaeologiae Regionalis Fontes”, t. 8, Olomouc.

Kwapiński M. 1987, Ryty i mity. O symbolice popielnic, Katalog wystawy, Gdańsk.

Lech P. 2013, Nowożytna studnia z Ostrowa Tumskiego w Poznaniu (stan. 9), Poznań (maszynopis pracy magisterskiej w Instytucie Prahistorii UAM).

Lech P., Sikorski A., Sprenger M. 2012, Najmniejszy wykop na Ostrowie Tumskim w Poznaniu (stan. 13), w: Poznań we wczesnym średniowieczu, red. H. Kóčka-Krenz, t. 7, Poznań, s. 215-227.

Makiewicz T. 1997, Wyobrażenia figuralne na naczyniach okresu przedrzymskiego i rzymskiego jako źródło do znajomości epoki, w: Archeologia i starożytnicy. Studia dedykowane Profesorowi Andrzejowi Abramowiczowi w 70 rocznicę urodzin, red. M. Głosek, Łódź, s. 185-193.

Malinowska M. 1961, Badania na stanowisku Ostrów Tumski 17 w Poznaniu w latach 1953-1954, w: Poznań we wczesnym średniowieczu, red. W. Hensel, t. III, Wrocław-Warszawa, s. 7-95.

Małachowicz M. 2005, Ceramika budowlana średniowiecznego Wrocławia, w: Wschodnia strefa Starego Miasta we Wrockawiu XII-XIV wieku. Badania na placu Nowy Targ, red. C. Buśko, Wrocław, s. 111-134.

Marcinkowski M. 2011, Fajans pomorski ze Starego Miasta w Elblagu, Elbląg.

Miazga A., Sankiewicz P., Sikorski A. 2012, Ceramika naczyniowa z badań wykopaliskowych przy murze Lubrańskiego na Ostrowie Tumskim w Poznaniu (ul. Posadzego 5), w: Poznań we wczesnym średniowieczu, red. H. Kóčka-Krenz, t. 7, Poznań, s. 43-103.

Munsell 1973, Munsell soil color charts, Baltimore.

Pochylski M., Kowalczyk A. 2012, Tak zwana ceramika husycka z Nowej Wsi, stan. 6, gm. Włocławek, woj. kujawsko-pomorskie, „Acta Universitatis Lodziensis”, Folia Archaeologica, t. 28, s. 227-245.

Sikorski A. 1991, Ryt figuralny i aplikacja plastyczna na wczesnośredniowiecznej ceramice naczyniowej z Dębczyna, woj. Koszalin, „Sprawozdania Archeologiczne”, t. 43, s. 281-287.

2003, Łekno, pow. Wągrowiec, woj. wielkopolskie, stan. 19. Wyniki badań nad ceramiką średniowieczną i nowożytną, „Studia i materiały do dziejów Pałuk”, t. 4, s. 67-123.

Skowrońska E. 2011, Ceramika budowlana z kompleksu klasztornego augustianów-eremitów w Stargardzie. Wprowadzenie do badań nad detalem, „Stargardia”, t. 6, s. 133-145.

Skrok Z. 2001, Skarby mate i duże, Warszawa.

Supryn M. 2008, Archeologia zamku w Janowcu. Dzieje budowli w świetle badań archeologicznych z lat 1976-2001, Janowiec.

Szántô T. 1986, Pismo i styl, Wrocław-Warszawa-Kraków-Gdańsk-Łódź.

Szwed R. 2004, Wczesnonowożytna ceramika naczyniowa z ul. Św. Antoniego we Wroctawiu, w: Wratislavia Antiqua, red. J. Piekalski, K. Wachowski, t. 6, Wrocław, s. 331-381.

Węgrzynowicz T. 2000, Uwagi o figurkach $i$ wizerunkach ptaków ze stanowisk kultury wysockiej, w: Kultura symboliczna kręgu pól popielnicowych epoki brązu i wczesnej epoki żelaza w Europie Środkowej, red. B. Gediga, D. Piotrowska, Warszawa-Wrocław-Biskupin, s. 227-236. 